\title{
DESCRIPTION OF A NEW ISOPOGON FROM NEW SOUTH WALES.
}

\author{
BY R. T. BAKER.
}

(Plate Xlu.)

\section{Isopogon Dawsoni, sp.nov.}

An erect shrub of 6 to 9 feet, so far as seen, the branches and young shoots hoary-tomentose. Leaves linear, 8 to 9 inches long, from very narrow at the base to about 2 lines broad near the apex, on long petioles: pinnate or deeply divided into 5-7 narrow segments, rarely entire, rigid, terminating in an almost pungent point, midrib slightly prominent on both sides, margins somewhat recurved. Cones terminal, sessile, solitary, globular, 6 lines in diameter after flowering. Outer bracts not numerous, hoary pubescent, prominent, subulate, the inner ones broader and shorter. Cone scales very numerous, acuminate, with narrow points prominent after flowering, obovate, closely imbricate, densely silky-hairy on the convex side, the exserted portion not so hairy, the tips or points pubescent.

Perianth yellow (?), probably purple (not yellow when collected), very silky villous, about 9 lines long, lobes of the corolla about half the length of the tube; stamens inserted in the corolla lobes; anthers sessile, the connective tipped with a small appendage; filaments flat, much shorter than the anthers. Style- end clavate, minutely papillose pubescent, the thickened part 4-angled, separated by a constriction from the bulbous base of the stigmatic termination. Receptacle under 6 lines.

Nearest affinity is 1. longifolius of South-Western Australia.

Loc.-Murrumbo Ranges, Goulburn River, near Widden, New South Wales.

This species is dedicated to Mr. Licensed Surveyor Dawson, of Henbury, Rylstone, who was instrumental in discovering this 
and other species, and has further aided botanical research by bringing to light varieties and species new for New South Wales.

I have to acknowledge my indebtedness to Mr. J. H. Maiden for his assistance in working out this description.

EXPLANATION OF PLATE.

Fig. 1. -Flower (slightly enlarged).

Fig. 2.-Corolla lobe (enlarged), showing stamens.

Fig. 3.-Cone scale, front view.

Fig. 4.-Cone scale, back view.

Fig. 5.-Cone scale, profile.

Fig. 6.--Outer bract.

Fig. 7.-Seed.

(Figs. 3-7 enlarged.) 


\section{$2 \mathrm{BHL}$ Biodiversity Heritage Library}

Baker, Richard T. 1895. "Description of a new Isopogon from New South Wales." Proceedings of the Linnean Society of New South Wales 9, 658-659. https://doi.org/10.5962/bhl.part.18133.

View This Item Online: https://www.biodiversitylibrary.org/item/29750

DOI: https://doi.org/10.5962/bhl.part.18133

Permalink: https://www.biodiversitylibrary.org/partpdf/18133

\section{Holding Institution}

MBLWHOI Library

\section{Sponsored by}

MBLWHOI Library

\section{Copyright \& Reuse}

Copyright Status: NOT_IN_COPYRIGHT

This document was created from content at the Biodiversity Heritage Library, the world's largest open access digital library for biodiversity literature and archives. Visit BHL at https://www.biodiversitylibrary.org. 